COVID-19 in people living with human immunodeficiency virus: a case series of 33 patients. Infection. 2020 May 11. [Epub ahead of print] https://doi.10.1007/s15010-02001438-z

6. Karmen-Tuohy S., Carlucci P.M., Zacharioudakis I.M., Zervou F.N., Rebick G., Klein E., Reich J., Jones S., Rahimian J. Outcomes among HIV-positive patients hospitalized with COVID-19. medRxiv. [This preprint report has not been peer-reviewed] https://www.medrxiv.org/content/ 10.1101/2020.05.07.20094797v1

7. $\mathrm{Wu}$ Q., Chen T., Zhang H. Recovery from COVID-19 in two patients with coexisted HIV infection. J Med Virol. 2020 May 13. [Epub ahead of print] https:// doi.10.1002/jmv.26006

8. Временные методические рекомендации по оказанию противотуберкулезной помощи в условиях пандемии новой коронавирусной инфекции (COVID-19). Общероссийская общественная организация «Российское общество фтизиатров». - 2020. -
46 c. // Temporary methodical recommendations on TB management in the conditions of the novel coronavirus infection (COVID-19) pandemic. The All-Russian Public Organization "Russian Society of Phthisiatricians", 2020, 46 p. (In Russ.)

9. Федеральные клинические рекомендации по диагностике и лечению туберкулеза у больных ВИЧ-инфекцией. М. - Тверь: Издательство «Триада». - 2014. - 56 c. // Federal clinical recommendations on diagnosis and management of TB in HIV-infected patients. Moscow - Tver, Triada, 2014, 56 p.

10. ВИЧ-инфекция у взрослых. Клинические рекомендации, утвержденные МЗ РФ. / Национальная ассоциация специалистов по профилактике, диагностике и лечению ВИЧ-инфекции. - 2020. - 530 с. // HIV infection in adults. Clinical recommendations endorsed by the Ministry of Health of the Russian Federation. The National Association of Specialists in Prevention, Diagnosis and Management of HIV infection, 2020, 530 p.

УДК: 616.24-002.5:616.379-008.64:616.441-002]-078:57.083.3

https://doi.org/10.52692/1857-0011.2021.1-69.12

\title{
INFLUENCE OF SODIUM SELENITE ON IMMUNOLOGICAL INDEXES OF TUBERCULOSIS PATIENTS WITH DIABETES MELLITUS AND AUTOIMMUNE THYROIDITIS
}

\author{
Svetlana MATVYEYEVA, PhD, associate professor. \\ Kharkov National Medical University, Kharkov, Ukraine \\ e-mail:kjara.clair@gmail.com
}

\section{Summary}

In 60 tuberculosis patients with diabetes mellitus and autoimmune thyroiditis serum level of selenium, thyroid state and immunological indexes were studied. Low level of selenium, subclinical hypothyroidism and weaken immunological response toward tuberculosis were diagnosed. Prescribing of selenite sodium with $200 \mu$ daily during 2 months normalized serum level of selenium, restored thyroid function and improved immunological response. Inclusion of selenite sodium in complex therapy of tuberculosis patients with diabetes mellitus and autoimmune thyroiditis after examination of serum level of selenium and thyroid state is recommended.

Key-words: tuberculosis, co-infection, diabetes mellitus, autoimmune thyroiditis.

Резюме. Влияние нитрата селена на показатели иммунитета у больных туберкулезом с сахарным диабетом и аутоиммунным тиреоидитом

У 60 больных туберкулезом с сахарным диабетом и аутоиммунным тиреоидитом изучались уровень селена в сыворотке крови, тиреоидный статус и показатели иммунитета. Диагностирован низкий уровень селена, субклинический гипотиреоз и снижения иммунного ответа на туберкулезную инфекцию. Назначение селенита натрия по 200 мг ежедневно в течение 2 месяцев нормализовало уровень селена в сыворотке крови, восстановило функцию щитовидной железы и улучшило иммунологический ответ. Рекомендуется включение селенита натрия в комплексную терапию пациентов с туберкулезом с сахарным диабетом и аутоиммунным тиреоидитом после исследования уровня селена в сыворотке крови тиреоидного статуса.

Ключевые слова: туберкулез, сахарный диабет, аутоиммунный тиреоидит. 


\begin{abstract}
Rezumat. Influența selenitului de sodiu asupra indicilor imunologici ai pacienților cu tuberculoză cu diabet zaharat și tiroidită autoimună

La 60 de pacienți cu tuberculoză cu diabet zaharat și tiroidită autoimună, s-a studiat nivelul seric de seleniu, starea tiroidiană și indicii imunologici. A fost diagnosticat un nivel scăzut de seleniu, hipotiroidismul subclinic și un răspuns imunologic slab față de tuberculoză. Prescrierea de selenit de sodiu cu $200 \mu$ pe zi pe parcursul a 2 luni a normalizat nivelul seric de seleniu, a restabilit funcția glandei tiroide și a îmbunătăţit răspunsul imunologic. Se recomandă includerea selenitului sodic în terapia complexă a pacienților cu tuberculoză cu diabet zaharat și tiroidită autoimună după examinarea nivelului seric de seleniu și a stării tiroidiene.
\end{abstract}

Cuvinte-cheie: tuberculoză, diabet zaharat, tiroidită autoimună.

Introduction. Convergence of the two world epidemics: tuberculosis and diabetes justify the relevance of the study of the features of the running of tuberculosis with comorbid diabetes [1]. Diseases of the thyroid gland are found in patients with diabetes mellitus in $11-30 \%[6,9,10]$. Hypothyroidism against the background of autoimmune thyroiditis worsens the outcomes of anti-tuberculosis chemotherapy [7] due to the suppressive effect of thyroid hormone deficiency on T-cell immunity [2]. However, not only iodine is needed for the normal functioning and maintenance of thyroid homeostasis, but also selenium. The selenium content in $1 \mathrm{~g}$ of thyroid tissue is greater than in other organs [8]. in the regions with a heavy iodide deficiency, the selenium deficiency is weighting hypothyroidism and leads to myxedema [11]. With autoimmune thyroid, in conditions of selenium deficiency, there was an inverse relationship between the level of selenium in the blood and the thyroid function $[8,11]$. Most authors pay attention to the positive effect of selenium additives on the immune system $[4,5]$.

The object of the study to detail the influence of selenite sodium on immunological indexes in tuberculosis patients with diabetes mellitus and autoimmune thyroiditis with subclinical hypothyroidism.

Materials and methods. The study included 60 patients with pulmonaryberculosis (TB) with concomitant diabetes mellitus (DM) and autoimmune thyroiditis. The patients were divided in 2 groups: 30 patients in observation group received $200 \mu \mathrm{g}$ of selenite sodium every day during 2 months of the intensive phase simultaneously with antituberculosis chemotherapy and other 30 patients of control group received antituberculosis chemotherapy only. Therapy for compensation for carbohydrate exchange was carried out in both groups. All patients were diagnosed with infiltrative destructive pulmonary tuberculosis and type I or II diabetes mellitus with secondary insulin dependence, and women predominated. Before starting treatment and at the end of intensive phase, serum levels of selenium in the laboratory "Synevo" (Germany) on the analyzer "PERKIN ELMER ZEEMAN AAS
4110", free thyroxine (free T4), thyroid-stimulating hormone of the pituitary gland (TSH), antibodies to thyroglobulin (TG) and thyroperoxidase (TPO) were determined by the immunoenzymatic method. At the same time, the parameters of cellular and humoral immunity were studied in patients of both groups. The state of T- and B-systems of immunity, natural killers was assessed. Phenotyping of lymphocytes was carried out and the relative content of T cells was determined: $\mathrm{CD} 3+$, T-helpers $\left(\mathrm{CD}^{+}\right)$, cytotoxic T-cells $(\mathrm{CD} 4+)$, B-lymphocytes $\left(\mathrm{CD} 19^{+}\right)$ and natural killer cells $\left(\mathrm{CD} 16^{+}\right)$. Using Vector Best reagents, the cytokine profile was determined: the levels of tumor necrosis factor- $\alpha$ (TNF- $\alpha$ ), interferon- $\gamma$ (INT- $\gamma$ ), interleukin-2 (Il-2), -6 (Il-6) and -4 (Il-4) before starting treatment and at the end of intensive phase. Statistical processing of the obtained data was carried out by the method of variation statistics using a standardized package of calculations Microsoft Excel XP. The probability of discrepancy between the mean values was determined by the Student's $t$ test. The critical level of significance $(\mathrm{P})$ when testing statistical hypotheses was taken equal to 0.05 .

Results. The results of the study of the serum level of selenium and the hormonal profile of both groups are presented in Table 1.

In both groups of patients with tuberculosis with concomitant diabetes and AIT with SH low level of selenium was marked. in taking of selenite sodium during 2 months normalized the serum level of selenium and restored of thyroid function

In both groups of patients with tuberculosis with concomitant diabetes and AIT before the start of treatment, low-normal values of free thyroxine are noted. At the same time, these patients also registered pathologically high initial levels of thyroid stimulating hormone (Table 1). These changes indicate the presence of a subclinical hypothyroidism (SH) with tuberculosis with concomitant diabetes mellitus and structural disorders of the thyroid gland by the type of autoimmune thyroiditis. There were no deviations from the norm at the initial level of antibodies to thyroglobulin in both groups. However, a high lev- 
The results of the study of the serum level of selenium and the hormonal profile in tuberculosis patients with concomitant diabetes mellitus and autoimmune thyroiditis with subclinical hypothyroidism

\begin{tabular}{|l|c|c|c|c|}
\hline \multirow{2}{*}{ Groups of patients } & \multicolumn{2}{|c|}{ Observation group (n=30) } & \multicolumn{2}{c|}{ Control (n=30) } \\
\cline { 2 - 5 } & Before treatment & 2 months later & Before treatment & 2 months later \\
\hline \multirow{2}{*}{$\mathrm{T}_{4}$ free $(\mathrm{pmol} / \mathrm{l})$} & $8,60 \pm 1,69$ & $12,45 \pm 1,58^{*}$ & $8,24 \pm 1,71$ & $6,87 \pm 1,67 \#$ \\
\hline TSH $(\mathrm{IU} / \mathrm{ml})$ & $4,57 \pm 0,91$ & $2,28 \pm 0,78^{*}$ & $4,51 \pm 0,87$ & $4,82 \pm 0,91 \#$ \\
\hline Antibodies to TG $(\mathrm{U} / \mathrm{ml})$ & $8,67 \pm 5,56$ & $8,34 \pm 5,66$ & $8,15 \pm 5,62$ & $8,56 \pm 5,34$ \\
\hline Antibodies to TPO $(\mathrm{U} / \mathrm{ml})$ & $136,16 \pm 8,96$ & $34,54 \pm 8,27^{*}$ & $140,54 \pm 8,79$ & $142,32 \pm 8,04 \#$ \\
\hline Selenium $(\mu / \mathrm{ml})$ & $58,23 \pm 6,54$ & $108,42 \pm 8,12^{*}$ & $60,31 \pm 7,50$ & $62,20 \pm 5,46 \#$ \\
\hline
\end{tabular}

Note:* - a reliable difference în indicators between groups $(\mathrm{p} \leq 0,5)$; \# - a reliable difference în indicators before and 2 months later $(\mathrm{p} \leq 0,5)$.

el of antibodies was recorded to thyroperoxidase in groups of patients with tuberculosis with concomitant diabetes and AIT with SH before the treatment began. Thus, the identified changes correspond to the autoimmune thyroid in these patients not only on the basis of a specific change in echograms, but also on the basis of both a hormonal criterion (subclinical hypothyroidism, most often accompanying autoimmune thyroiditis in the deployed stage) and on the basis of an immunological criterion (an increase in antibodies to TPO). in the serum of patients of both groups with lung tuberculosis with concomitant diabetes and autoimmune thyroiditis, a reduced selenium level was installed (Table 1).

At the end of the intensive therapy phase with the inclusion of sodium selenite in the observation group, the level of selenium level is noted: from $(58.23 \pm 6.54) \mu \mathrm{g} / \mathrm{ml}$ to $(108.42 \pm 8.12) \mu \mathrm{g} / \mathrm{ml}$; Free thyroxine levels: from $(8.60 \pm 1.69) \mathrm{PMOL} / \mathrm{L}$ to $(12.45 \pm 1.58) \mathrm{PMOL} / \mathrm{L}$ and thyroid stimulating hormone from $(4.37 \pm 0.91) \mathrm{MCED} / \mathrm{ml}$ to $(2.28 \pm$ $0.78) \mathrm{MCED} / \mathrm{ml}$, as well as decreased to the permissible values of the antibody titer to thyroperoxidase from $(136.16 \pm 8.96) \mathrm{un} / \mathrm{ml}$ to $(34.54 \pm 8.27)$ $\mathrm{U} / \mathrm{ml}$. in this case, a low level of selenium remains in the comparison group: $(60.31 \pm 7.50) \mu \mathrm{g} / \mathrm{ml}$ and $(62.20 \pm 5.4) \mu \mathrm{g} / \mathrm{ml}$ and against the background of chemotherapy there is a further decrease in the level of free thyroxine compared to the initial level (8.24 $\pm 1.71) \mathrm{PMOL} / \mathrm{L}$ TO $(6.87 \pm 1.67 \mathrm{PMOL} / \mathrm{L})$, still there is a high level of thyroid stimulating hormone $(4.51 \pm 0.87) \mathrm{MCED} / \mathrm{ml}$ and $(4.82 \pm 0.91) \mathrm{MCED}$ $/ \mathrm{ml}$. Thus, the appointment of sodium selenite for 2 months leads to normalization of the selenium level in patients with tuberculosis against the background of endocrine pathology and restores disturbed thyroid homeostasis.

The results of the study of immunological indexes in tuberculosis patients with concomitant diabetes mellitus and autoimmune thyroiditis with subclinical hypothyroidism are present in table 2 .

The study of the immune system reveals deviations in the parameters of initial cellular immunity in both groups. 2 months later in the observation group, has been receiving selenite sodium there was a significant increase of leukocytes, mononuclear cells and pan-lymphocytes $\left(\mathrm{CD}^{+}\right)$in comparison with the control. The levels of the subpopulations of T-helpers $\left(\mathrm{CD}^{+}\right)$and IRI also were increased in patients of observation group. (Table 2). The levels of immunoglobulins $\mathrm{G}, \mathrm{A}$ and $\mathrm{M}$ were increased to the end of intensive phase in observation group compared with the control.

In TB patients with $\mathrm{DM}+\mathrm{AIT}$ of observation group, the level of TNF- $\alpha$ increased more than twice after receiving selenite sodium. The level of INT- $\gamma$ increased in 2.3 times more in observation group when compared with control group. The content of IL-2 in the systemic blood flow of TB/DM patients of observation group increased of 2.5 times compared with the control.

Level of IL-4 in TB patients with DM and AIT and $\mathrm{SH}$ of observation group decreased compared with the control group.

Discussion. Thus, the results of the study demonstrate an improving change in all branches of immunity in tuberculosis patients with DM and AIT with SH after 2 months receiving of selenite sodium. Intensifying of the immunity were accompanied by stimulation of thyroid function under the influence of selenite sodium. So, selenite stimulates both humoral 
Table 2

The results of the study of immunological indexes în tuberculosis patients with concomitant diabetes mellitus and autoimmune thyroiditis with subclinical hypothyroidism

\begin{tabular}{|l|c|c|c|c|}
\hline \multirow{2}{*}{ Groups } & \multicolumn{2}{c|}{ Observation group (n=30) } & \multicolumn{2}{c|}{ Control group (n=30) } \\
\cline { 2 - 5 } & Before treatment & 2 months later & Before treatment & 2 months later \\
\hline Leucocytes, $10^{9 / 1}$ & $5,34 \pm 0,82$ & $7,78 \pm 0,92$ & $5,67 \pm 0,69$ & $5,65 \pm 0,55$ \\
\hline Monocytes, \% & $31,45 \pm 3,21$ & $41,32 \pm 2,54$ & $32,05 \pm 2,98$ & $33,45 \pm 2,76$ \\
\hline CD3 $^{+}$ & $43,27 \pm 2,89$ & $58,43 \pm 3,3$ & $44,56 \pm 2,44$ & $45,23 \pm 2,89^{*}$ \\
\hline CD4+ & $25,35 \pm 2,76$ & $35,87 \pm 3,8$ & $26,23 \pm 2,45$ & $26,33 \pm 2,65^{*}$ \\
\hline CD8 $^{+}$ & $16,32 \pm 1,92$ & $18,66 \pm 1,78$ & $17,73 \pm 1,43$ & $17,35 \pm 1,47$ \\
\hline IRI & $1,37 \pm 1,78$ & $1,92 \pm 1,87$ & $1,48 \pm 1,65$ & $1,52 \pm 1,45$ \\
\hline CD19 & $13,38 \pm 2,84$ & $18,76 \pm 1,59$ & $14,83 \pm 2,48$ & $14,33 \pm 2,43$ \\
\hline NK-cells $\left(\mathrm{CD} 16^{+}\right)$ & $14,83 \pm 2,72$ & $19,89 \pm 1,76$ & $14,83 \pm 2,72$ & $16,45 \pm 2,65$ \\
\hline IgG & $1,51 \pm 0,42$ & $4,67 \pm 1,08$ & $1,98 \pm 0,23$ & $1,71 \pm 0,44^{*}$ \\
\hline IgM & $0,52 \pm 0,52$ & $2,05 \pm 1,51$ & $0,65 \pm 0,87$ & $0,87 \pm 0,45^{*}$ \\
\hline IgA & $14,78 \pm 1,82$ & $20,23 \pm 1,61$ & $15,23 \pm 1,82$ & $15,67 \pm 1,78^{*}$ \\
\hline TNF- $\alpha(\mathrm{pmol} / \mathrm{ml})$ & $27.88 \pm 14.27$ & $60.44 \pm 15,01$ & $28.56 \pm 13.99$ & $28.54 \pm 14.89^{*}$ \\
\hline INT- $\gamma(\mathrm{pmol} / \mathrm{ml})$ & $2.33 \pm 0.18$ & $4.98 \pm 0.54$ & $2.67 \pm 0.96$ & $2.54 \pm 0.84^{*}$ \\
\hline IL-2 $(\mathrm{pmol} / \mathrm{ml})$ & $3.12 \pm 0,50$ & $7.09 \pm 0.89$ & $3.65 \pm 0,81$ & $3.21 \pm 0,50^{*}$ \\
\hline IL-6 $(\mathrm{pmol} / \mathrm{ml})$ & $14.89 \pm 1.18$ & $39.66 \pm 1.44$ & $15.32 \pm 1.18$ & $15.21 \pm 1.81^{*}$ \\
\hline IL-4 $(\mathrm{pmol} / \mathrm{ml})$ & $0.070 \pm 0,009$ & $0.011 \pm 0,003$ & $0.078 \pm 0,008$ & $0.073 \pm 0,007^{*}$ \\
\hline
\end{tabular}

Note: * - a reliable t difference în indicators between groups $(\mathrm{p}<0.05)$.

and cellular immunity by restoring thyroid function. These results, as well as data of the effect of administration of thyroid hormone in vivo and in vitro, indicate an important role of thyroid hormones in modulating the activity of natural killer cells. The results are corresponding with other studies. [3,9], showing a positive association of thyroid hormone concentration with inflammatory markers activated by T-cells, NK-interleukin-6 expression by activated monocytes, and a higher density of interleukin-2 receptors in $\mathrm{T}$ cells and thus shedding light on the mechanisms by which the endocrine system is able to influence the severity of immunity.

\section{References}

1. Baker M.A., Harries A.D., Jeon C.Y. et al The impact of diabetes on tuberculosis treatment outcomes: a systematic review Tuberculosis, lung diseases, HIV infection, 2016; 27 (4): 66-79.

2.Cherenco S.O. Matvyeyeva S.L. Correlations between clinical running of tuberculosis, thyroid function and some cytokines Ukr. pulm. journal, 2011; 2: 35-8.

3. Hodkinson C.F., Simson E.E.A., Beattie J.H. et al. Preliminary evidence of immune function modulation by thyroid hormones in healthy men and women aged 55-70 years Endocrinol., 2009; 202: 55-63.

\section{Conclusions}

1. In tuberculosis patients with diabetes and AIT with subclinical hypothyroidism initially low serum level of selenium was marked.

2. Selenite sodium in taken with $200 \mu$ every day during 2 months normalized serum level of selenium and restored thyroid function

3. The indexes of both branches of the immunity improved by administration of selenite sodium during 2 months.

4. Selenite sodium could be recommended for concomitant therapy in TB patients with DM and AIT after examination of serum level of selenium and thyroid state.

4. Huong Z., Rose A.H., Hoffman P.R. The role of selenium in inflammation and immunity: from molecular mechanisms to therapeutic opportunities Antioxidants \& Redox Signaling, 2012; 16 (7): 705-743.

5. Hussain M.J., Ahmed W., Nasir M. et al Immune modulatory and antioxidative effect of selenium against pulmonary tuberculosis Pak. J. Pharm. Sci Supplementary, 2019; 32 (2): 779-784.

6. Kadiyala R., Peter R., Okosieme O.E. Thyroid dysfunction in patients with diabetes: clinical implications and screening strategies Internat. Journal of Clin. Practice, 2010; 64: 1130-9. 
7. Matvyeyeva S.L. Influence of functional state of thyroid on the indexes of the immunity of tuberculosis patients Tuberculosis, lung diseases, HIV infection, 2016; 25(2): 40-3.

8. Stuss M., Michalska-Kasiczok M., Sewerynek E. The role of selenium in thyroid gland pathphisiology Endokrinologia Polska, 2017; 68(4): 440-46.

9. Stagi S, Azzari C., Bindi G. et al. Undetectable serum IgA and low IgM concentrations in children with con- genital hypothyroidism Clin. Immunol, 2005; 116: 94-8.

10. Tomer Y., Menconi F. Type 1 diabetes and autoimmune thyroiditis: the genetic connection Thyroid, 2009; 19: 99-102.

11.Van Zuuren E.J., Albusta A.Y., Fedorowicz Z., Carter B., Pijl H. Selenium supplementation for hashimoto's thyroiditis: Summary of a cochrane systematic review Eur. Thyroid J. 2014;3:25-31.

CZU: 612.014:616.24-002.5+578.834.1COVID-19

https://doi.org/10.52692/1857-0011.2021.1-69.13

\title{
PARTICULARITĂȚI ALE REACTIVITĂȚII IMUNOLOGICE, PRODUCERII DE OXID NITRIC ȘI A METABOLIȚILOR LUI LA PACIENŢII CU TUBERCULOZĂ PULMONARĂ ÎN ASOCIERE CU INFECT,IA COVID-19
}

\author{
Serghei GHINDA ${ }^{1}$., dr. hab. în șt. med., prof. cercet., \\ Elena TUDOR ${ }^{1}$, dr. în șt. med., conf. cercet., membru-coresp. AȘMM, Tatiana OSIPOV ${ }^{2}$, \\ Valentina CHIROȘCA ${ }^{1}$, dr. în șt. biol., conf. cercet., Valeriana PANTEA ${ }^{2}$, \\ Zinaida CIOBANU ${ }^{1}$, Galina CRIVENCO ${ }^{1}$, dr. în șt. med., conf. cercet., \\ Valentin GUDUMAC ${ }^{2}$, dr. hab. în șt. med., prof. univer.
}

'ISMP Institutul de Ftiziopneumologie „Chiril Draganiuc”, Chișinău, R. Moldova, ${ }_{2}^{2}$ IP Universitatea de Stat de Medicină şi Farmacie „Nicolae Testemiţanu”, Chișinău, R. Moldova

e-mail: ginda-sergei@mail.ru

\section{Rezumat}

Studiul a inclus 24 de pacienți, care au constituit lotul de bază - 12 pacienți cu tuberculoză pulmonară în asociere cu infecția COVID-19 și lotul de control - 12 pacienți cu tuberculoză pulmonară. S-a studiat formula leucocitară, conținutul de limfocite $\mathrm{CD} 3, \mathrm{CD} 4, \mathrm{CD} 8$, conținutul de $\mathrm{NO}_{2}{ }^{-}+\mathrm{NO}_{3}{ }^{-}$total și metaboliții săi. Rezultatele obținute au demonstrat, că la pacienții cu tuberculoză pulmonară asociată cu COVID-19 se determină o scădere pronunțată a limfocitelor și o deplasare nesemnificativă a formulei leucocitare spre stânga, Conținutul limfocitelor scad datorită limfocitelor CD3 și subpopulației acestora de limfocite CD4 (helper). Indicele de imunoreglare CD4/CD8 demonstrează stimularea rectivităţii imunologice la pacienții cu tuberculoză pulmonară și depresie a reactivității imunologice la pacienții cu tuberculoză pulmonară asociată cu infecția COVID-19 și o suprimare pronunțată a producției conținutului de $\mathrm{NO}_{2}^{-}+\mathrm{NO}_{3}^{-}$total - și metaboliții săi $\left(\mathrm{NO}_{2}^{-}\right.$şi $\left.\mathrm{NO}_{3}^{-}\right)$.

Cuvinte-cheie: tuberculoză pulmonară, COVID-19, imunologie, biochimie.

Summary. Particularities of immunological reactivity, nitric oxide and its metabolities production in patients with pulmonary tuberculosis in association with COVID-19 infection

The study included 24 patients, which formed the baseline group - 12 patients with pulmonary tuberculosis in combination with COVID-19 infection and the control group - 12 patients with pulmonary tuberculosis. There were studied the leukocyte formula, the content of CD3, CD4, CD8 lymphocytes, the content of $\mathrm{NO}_{2}{ }^{-}+\mathrm{NO}_{3}{ }^{-}$total and its metabolites. The obtained results showed that in patients with pulmonary tuberculosis and COVID-19 there is a pronounced decrease of lymphocytes and an unexpressed shift of the leukocyte formula to the left. The lymphocyte content decreases due to CD3 lymphocytes and their subpopulation of CD4 (helper) lymphocytes. The CD4/CD8 immunoregulatory index demonstrates a stimulation of immunological reactivity in patients with pulmonary tuberculosis and depression of immunological reactivity in patients with pulmonary tuberculosis in combination with COVID-19 infection and a pronounced suppression of the production content of $\mathrm{NO}_{2}^{-}+\mathrm{NO}_{3}^{-}$total and its metabolites $\left(\mathrm{NO}_{2}^{-}\right.$and $\left.\mathrm{NO}_{3}^{-}\right)$.

Key-words: pulmonary tuberculosis, COVID-19, immunology, biochemistry. 